\title{
Evaluation of nephroprotective and cytotoxic effect of ethanolic extract of Mikania scandens leaves by using alloxan- induced diabetic nephropathy mice
}

Koushik Ahammed ${ }^{1 *}$, Md. Hasibul Hasan Joardar ${ }^{1}$, Maruf ul Islam ${ }^{1}$, Md. Ben Yameen ${ }^{1}$, S. M. Mushiur Rahman ${ }^{1}$ and Rokshana Sharmin ${ }^{2}$

\begin{abstract}
Background: Diabetic is one of the fundamental persuasive of diabetic nephropathy and significantly sparks off kidney diseases and end stage renal failure globally.

Method: The current research was carried out to evaluate hypoglycemic potential and nephroprotective effect of ethanolic extract of Mikania scandens leaves by using alloxan-induced diabetic nephropathy (DN) mice. The mice were intraperitoneally treated with $(200 \mathrm{mg} / \mathrm{kg})$ Mikania scandens leaves extract and standard $(120 \mathrm{mg} / \mathrm{kg})$ metformin HCL solution up to 22 days. During this treatment period, we collected blood for evaluation of different types of parameters such as blood glucose level body weight at 0,15, 22th days, serum creatinine, uric acid, total protein were estimated at the end of the experiment (day 22).

Result: Mikania scandens leaves extract significantly $(p<0.05)$ lessen blood glucose level, serum creatinine, total protein and uric acid. Apart this, cytotoxicity studies were assessed by Brine Shrimp Lethality Bioassay. By this method, we measure the dose of $\mathrm{LC}_{50}$. The plant has high $\mathrm{LC}_{50}$ dose thus cytotoxicity has ensued at massive amount and safe to administer.
\end{abstract}

Conclusion: Lowering of serum creatinine, uric acid and total protein recommend that the ethanolic extract of Mikania scandens possess potent nephroprotective activity and assure the traditional avail of this plant in the management of diabetes nephropathy.

Keywords: Mikania scandens, Diabetic, Nephroprotective, Cytotoxic

\section{Background}

Diabetic kidney disease is a leading phenomenon of chronic and end-stage-renal disease worldwide and the prime predictor of mortality in patient with diabetes [1]. Diabetic nephropathy is a chronic complication of both type $1 \mathrm{DM}$ and type $2 \mathrm{DM}$ [2]. Approximately, 30\% of all diabetic patients metamorphose into diabetic nephropathy

\footnotetext{
* Correspondence: koushikahamed11@gmail.com

'Department of Pharmacy, Faculty of Biological Science, Jessore University of Science and Technology, Jessore 7408, Bangladesh

Full list of author information is available at the end of the article
}

after $10-20$ years of diabetes [3]. DN characterized by high blood pressure, proteinuria, a progressive decline in renal function and hike the risk of cardiovascular disease, is becoming more and more prevalent to the extent that it has touched epidemic proportion [4]. Abnormalities in DN with long-standing poorly control blood glucose level. This is followed by multiple alterations in filtration units in the kidneys, the nephrons [5]. Initially, there is constriction of the efferent arteriole and dilation of the afferent arteriole, with resulting glomerular capillary hypertension
Springer Open (c) The Author(s). 2020 Open Access This article is licensed under a Creative Commons Attribution 4.0 International License, which permits use, sharing, adaptation, distribution and reproduction in any medium or format, as long as you give appropriate credit to the original author(s) and the source, provide a link to the Creative Commons licence, and indicate if changes were made. The images or other third party material in this article are included in the article's Creative Commons licence, unless indicated otherwise in a credit line to the material. If material is not included in the article's Creative Commons licence and your intended use is not permitted by statutory regulation or exceeds the permitted use, you will need to obtain permission directly from the copyright holder. To view a copy of this licence, visit http://creativecommons.org/licenses/by/4.0/. 
Table 1 Effects of EMSL on body weight in alloxan induced diabetic nephropathy mice

\begin{tabular}{llll}
\hline Groups & \multicolumn{3}{l}{ Body weight comparison level } \\
\cline { 2 - 4 } & At Oth day & At 15th day & At 22th day \\
\hline Control & $21.26 \pm 0.90973$ & $28.32 \pm 1.34625$ & $30.84 \pm 1.85408$ \\
MS-200 mg/kg & $22.86 \pm 0.96208$ & $20.54 \pm 0.65468$ & $20.02 \pm 0.55082$ \\
Diabetic control & $20.00 \pm 2.49319$ & $24.78 \pm 2.04436$ & $27.90 \pm 1.96061$ \\
Standard & $19.48 \pm 1.01755$ & $19.18 \pm 0.57219$ & $18.70 \pm 1.45327$ \\
\hline
\end{tabular}

Values are expressed as mean \pm SEM (Standard Error of Mean) of

five experiments

and hyperfiltration; this gradually changes to hypofiltration over time [6].

Mikania scandens (L) is popularly used as a herbal remedy for various ailments of Bangladesh. The genus Mikania is a member of family Asteraceae (Compositae). In Bangladesh, M. scandens is known as "Jarmany lota" [7]. The main phytochemical groups of the plant are coumarins and derivatives, sesquiterpenes, sesquiterpenes lactones, diterpenes, phytosterol or terpenoids and flavonoids [8]. M. scandens is used in folk medicine for the treatment of stomach ulcers, diarrhea, blood coagulant and scabies [9-11]. In-vitro experiments asserted that the flowers exposed anti-inflammatory properties [12]. It has analgesic, in vitro antioxidant and antidiabetic activities of leaf material [13].

Brine shrimp lethality bioassay is a simple, high throughput cytotoxicity test of bioactive chemicals. It is based on the killing ability of test compounds on sample zoological organism brine shrimp (Artemia salina) [14]. It's a preliminary toxicity screen for further experiment on mammalian animal models.

The purpose of the study is to investigate the ethanolic extract of Mikania scandens leaves experimentally induce diabetic nephropathy mice and assess the toxic level of this plant. In future, we want to isolate the compound of plant leaves extract and run further experiment.

\section{Materials and methods Plant collection}

Fresh leaves of Mikania scandens were collected from medicinal plant garden at Jashore University of Science and Technology, Jashore, Bangladesh. Leaves were shed dried and grind with electric grinder into coarse powder.

\section{Preparation of crude extract}

Coarse powder of Mikania scandens leaves soaked in 95\% ethanol for 7 days at room temperature with occasional shaking and stirring. The solvent were filtered through cotton and then through a filter paper. The ethanolic solution was allowed to evaporate using a rotary evaporator. Then the collected extract was preserved in a refrigerator for the analysis of cytotoxic and pharmacologic properties.

\section{Experimental animals}

Healthy male Swiss albino mice were procured from Jahangir Nagar University. They were housed in polypropylene cages and maintained under standard conditions. The study protocol was approved by institutional ethical committee (Ref: ERC/FBS/JUST/2018-12).

\section{Chemical and drug collection}

Standard antidiabetic agent metformin hydrochloride was the generous gift sample from square pharmaceuticals Ltd. Bangladesh. Alloxan was purchased from seico research laboratories Ltd. Mumbai, India. Tween-80 was obtained from BDH chemical, UK and saline solution was collected from Beximco infusion Ltd., Bangladesh. URCA

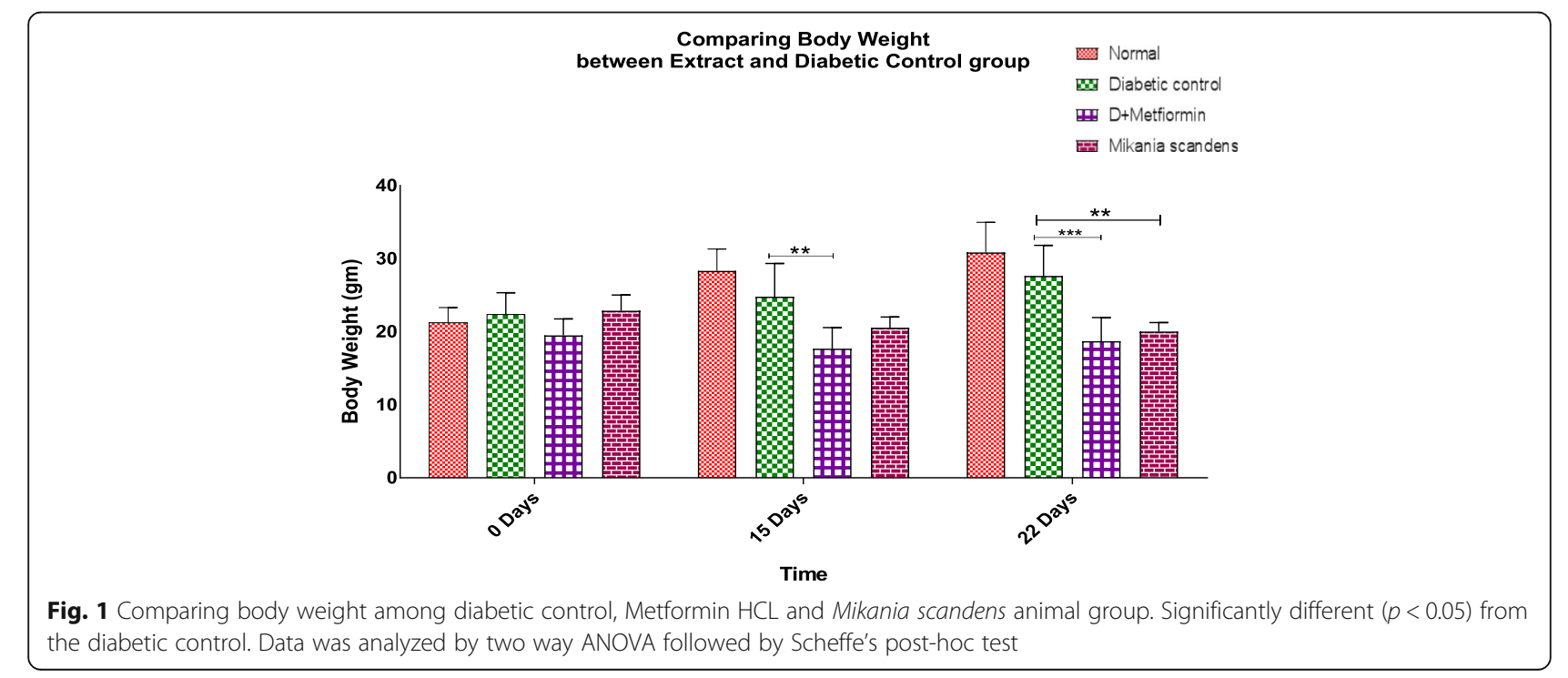


Table 2 Effects of EMSL on blood glucose level in alloxan induced diabetic nephropathy mice

\begin{tabular}{llll}
\hline Groups & \multicolumn{3}{l}{ Blood glucose comparison level } \\
\cline { 2 - 4 } & At 0th day & At 15th day & At 22th day \\
\hline Control & $5.22 \pm 0.75987$ & $5.68 \pm 0.35693$ & $7.80 \pm 0.97929$ \\
MS-200 mg/kg & $24.30 \pm 2.8066$ & $6.68 \pm 1.31848$ & $5.68 \pm 1.35956$ \\
Diabetic control & $14.86 \pm 1.00230$ & $12.56 \pm 3.78188$ & $21.08 \pm 2.85577$ \\
Standard & $24.18 \pm 2.52456$ & $8.20 \pm 1.61555$ & $7.72 \pm 1.43611$ \\
\hline
\end{tabular}

Values are expressed as mean \pm SEM (Standard Error of Mean) of

five experiments

Flex reagent cartilage, CRE2 Flex reagent cartilage, TP Flex reagent cartilage, is registered trade mark of Fresenius, Kabi AG, Bad Humburg, Germany.

\section{Hypoglycemic effect of leave extract Induction of diabetes}

After overnight fasting, a freshly prepared solution of alloxan monohydrate $(200 \mathrm{mg} / \mathrm{kg}$ body weight in normal saline) was administered intraperitoneally. After $48 \mathrm{~h}$ blood glucose content was measured by a Glucometer (SAFE TOUCH Glucometer, HMD Biomedical Inc., Taiwan technology of USA). Mice with blood glucose level above $11.1 \mathrm{mmol} / \mathrm{L}$ were selected for the study [15]. Their base line blood glucose level was also measured just prior to the administration of alloxan.

\section{Experimental design}

Mice were divided into four groups consisting of five animals in each group. Group 1 (Normal control): Normal mice treated with saline $1 \mathrm{ml} / \mathrm{kg}$. Group 2 (Diabetic control): Diabetic mice give no treatment. Group 3 (EMSL $200 \mathrm{mg} / \mathrm{kg}$ ): Diabetic mice treated with $200 \mathrm{mg} / \mathrm{kg}$ body weight p.o. of Mikania scandens leave extract once a day. Group 4 (Positive control): Diabetic mice treated with $120 \mathrm{mg} / \mathrm{kg}$ p.o. body weight of metformin hydrochloride once a day.

\section{Determination of blood glucose level}

All blood samples were collected by cutting the tail tip of the mice. Blood samples were collected from the tail at intervals of $0,15,22$ th days.

\section{Diabetic nephroprotective effect of leave extract}

After completing the 22th day's blood glucose testing, the mice were sacrificed and $3-5 \mathrm{ml}$ of blood was collected direct from the heart by syringes, centrifuged at $4000 \mathrm{rpm}$ for $10 \mathrm{~min}$ and the serum was obtained.

\section{Uric acid test}

Uric acid was analyzed by URCA Flex reagent cartilage. Uric acid, which absorbs light at $293 \mathrm{~nm}$, is converted by uricase allantoin which is non-absorbing at $293 \mathrm{~nm}$. The change in absorbance at $293 \mathrm{~nm}$ due to disappearance of uric acid is directly proportional to the concentration of uric acid in the sample and is measured by using a bichromatic $(293,700)$ end point technique.

\section{Total protein test}

Total protein analyzed by TP Flex reagent cartilage. $\mathrm{Cu}-$ pric ion reacts with the peptide linkage of the protein in a basic solution. The blue copper (II) protein complex thus formed is proportional to the total protein concentration in the sample and is measured by using a bichromate $(540,700)$ end point technique.

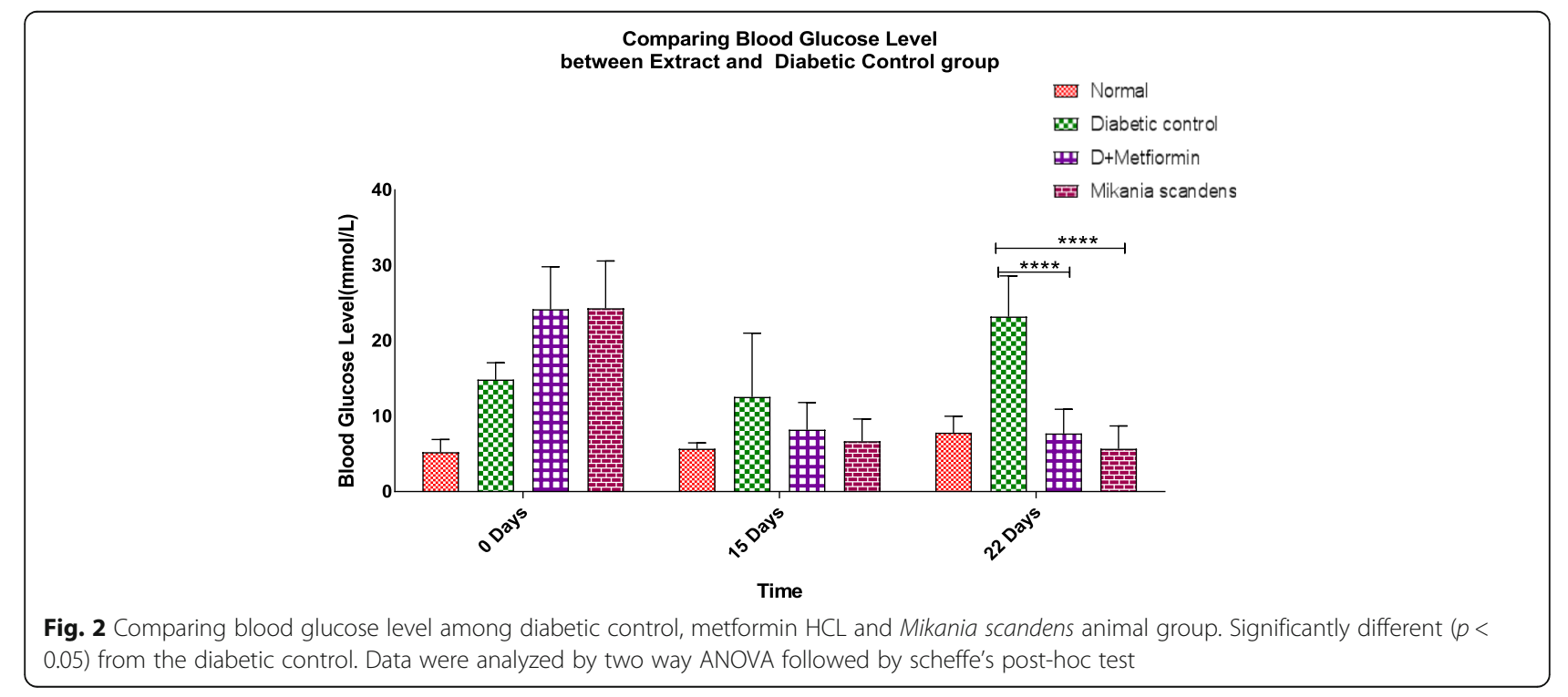


Table 3 Effect of EMSL on serum creatinine level on alloxan induced diabetic nephropathy mice

\begin{tabular}{ll}
\hline Group & Serum creatinine comparison level (22th day) \\
\hline Control & $0.5800 \pm 0.01528$ \\
MS-200 mg/kg & $0.5800 \pm 0.02082$ \\
Diabetic control & $0.5667 \pm 0.04410$ \\
Standard & $0.8300 \pm 0.04041$ \\
\hline
\end{tabular}

Values are expressed as mean \pm SEM (Standard Error of Mean) of five experiments

\section{Serum creatinine test}

Creatinine is analyzed by CRE2 Flex reagent cartilage. The CRE2 method uses a modified kinetic Jaffe Technique. In presence of a strong bases such a $\mathrm{NaOH}$, picrate reacts with creatinine to form a red chromophore. The rate of increasing absorbance at $520 \mathrm{~nm}$ due to formation of this chromophore directly proportional to the total protein concentration in the sample and is measured by a bi-chromatic $(510,600)$ rate technique. Bilirubin is oxidized by potassium fericyanide to prevent interference.

\section{Cytotoxic effect of leaf extract}

\section{Brine shrimp lethality bioassay}

Cytotoxicity of plant extract can be determined through brine shrimp lethality bioassay followed by the method of Meyer et al. [16]. Sea water was used for performing the hatching of Artemia salina Leach (Brine shrimp eggs) into mature nauplii (Larvae) within $48 \mathrm{~h}$ at $25^{\circ} \mathrm{C}$. The sea water contained 10 nauplii, where the test solutions were added that were diluted serially then the number of alive larvae was counted after $24 \mathrm{~h}$ incubation period that was carried out at $25^{\circ} \mathrm{C}$.

\section{Statistical analysis}

Data are expressed as mean \pm SEM (standard error of mean). For statistical evaluation of all test results, oneway ANOVA following Dunnett's test $(P<0.05$, vs. diabetic control) was utilized. For the analysis of all data and graph generation, SPSS software (version 20; IBM Corporation, New York, USA) and Graph Pad Prism software (version 5; San Diego, California, USA) were used, respectively. The obtained results are compared with the diabetic control group. The significance is determined at the level of $P<0.05$.

\section{Results}

Effects of EMSL on body weight in alloxan induced diabetic nephropathy mice

The effect of intra-peritoneal administration of alcoholic leaves extract of Mikania scandens in diabetic nephropathy mice is presented in Table 1 and Fig. 1. A gradual raise in body weight gain was observed in the control group of animals. A slight improvement in body weight gain was seen in diabetic control group whether standard and Mikania scandens groups were showed a little loss of body weight.

Effects of EMSL on blood glucose level in alloxan induced diabetic nephropathy mice

The effect of intra-peritoneal administration of alcoholic leaves extract of Mikania scandens in diabetic nephropathy mice is shown in Table 2 and Fig. 2. Alloxan-induced diabetic mice showed approximately two fold uplift of blood glucose level at 22th day. Administration of alcoholic extract at dose of $200 \mathrm{mg} / \mathrm{kg}$ to alloxan-induced diabetic mice cause diminution of blood glucose level which was significant $(p<0.05)$. Metformin $\mathrm{HCL}$ at $120 \mathrm{mg} / \mathrm{kg}$

Comparing Serum Creatinine Level between

Extract and Diabetic control group

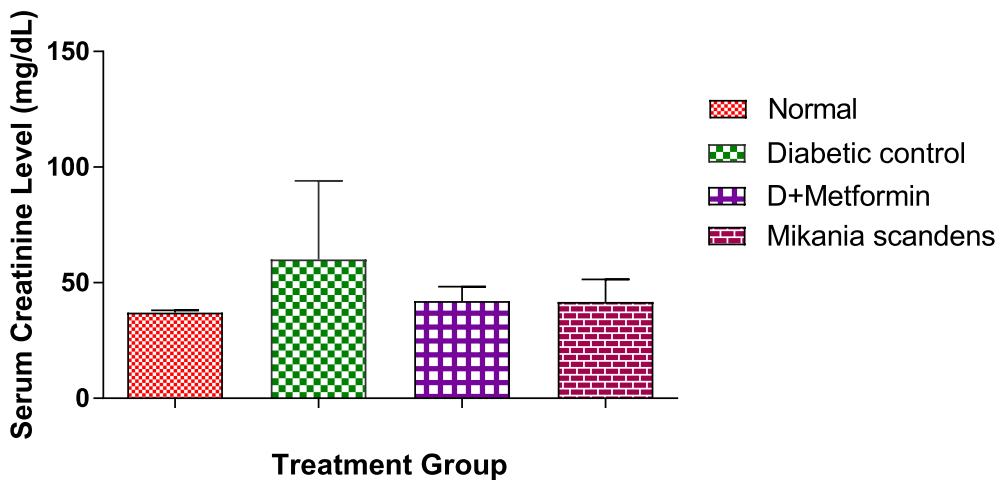

Fig. 3 Comparing serum creatinine level among diabetic control, metformin HCL and Mikania scandens animal groups. Significant different ( $p<$ 0.05) from the diabetic control. Data were analyzed by one way ANOVA followed by scheffe's post-hoc test 
Table 4 Effect of EMSL on serum uric acid level in alloxan induced diabetic nephropathy mice

\begin{tabular}{ll}
\hline Group & Serum uric acid comparison level (22th day) \\
\hline Control & $6.3167 \pm 0.10990$ \\
MS-200 mg/kg & $4.2333 \pm 0.22400$ \\
Diabetic control & $8.8433 \pm 0.14881$ \\
Standard & $3.1000 \pm 0.23692$ \\
\hline
\end{tabular}

Values are expressed as mean \pm SEM (Standard Error of Mean) of five experiments

exhibited significant $(p<0.05)$ reduction in blood glucose level when compared to diabetic control.

\section{Effect of EMSL on serum creatinine level on alloxan} induced diabetic nephropathy mice

Comparing serum creatinine level among diabetic control, Metformin HCL and Mikania scandens groups by using alloxan induce diabetic nephropathy mice are displayed in the Table 3 and Fig. 3. No significant result was found among diabetic control, Metformin HCL and Mikania scandens groups.

Effect of EMSL on serum uric acid level in alloxan induced diabetic nephropathy mice

Comparing serum uric acid among diabetic control, metformin HCL and Mikania scandens groups by using alloxan induce diabetic nephropathy mice are presented in the Table 4 and Fig. 4. Alcoholic extract at dose 200 $\mathrm{mg} / \mathrm{kg}$ and metformin HCL $120 \mathrm{mg} / \mathrm{kg}$ cause decrement of serum uric acid level which was significant $(p<0.05)$.

Effects of EMSL on total protein level in alloxan induced diabetic nephropathy mice

Comparing total protein level among diabetic control, metformin HCL and Mikania scandens groups are shown in the Table 5 and Fig. 5. Mikania scandens and
Table 5 Effects of EMSL on total protein level in alloxan induced diabetic nephropathy mice

\begin{tabular}{ll}
\hline Group & Protein comparison level (22th day) \\
\hline Control & $5.3333 \pm 0.13383$ \\
MS-200 mg/kg & $4.6800 \pm 0.19732$ \\
Diabetic control & $7.7333 \pm 0.32441$ \\
Standard & $6.7333 \pm 0.23786$
\end{tabular}

Values are expressed as mean \pm SEM (Standard Error of Mean) of five experiments

standard group showed significant $(p<0.05)$ downfall of total protein level when compared to diabetic control group.

\section{Cytotoxic effect of EMSL on brine shrimp lethality bioassay}

As a dose dependent manner, the mortality rate of brine shrimp was found to be onward with accretive concentration of the sample. The median lethal concentrations at which $50 \%$ lethality $\left(\mathrm{LC}_{50}\right)$ of brine shrimp nauplii occurrence were found to be $1083 \mu \mathrm{g} / \mathrm{ml}$ for the crude extract of Mikania scandens which was displayed at Table 6 and Fig. 6.

\section{Discussion}

Medicinal plants being the potential sources of bioactive agents are gaining acceptability worldwide. Safe, effective and indigenous remedies are gaining popularity equally among the people of both the urban and rural areas [17]. The major reason of death among patients with diabetic nephropathy was uraemia (66\%) [18]. Anti-hyperglycemic effect was determined by blood glucose measuring at different intervals, while nephroprotective activity analysis against alloxan induced toxicity was performed. Sustained decrease in hyperglycemia will diminish the danger of

Comparing Uric Acid level

between Extract and Diabetic Control group

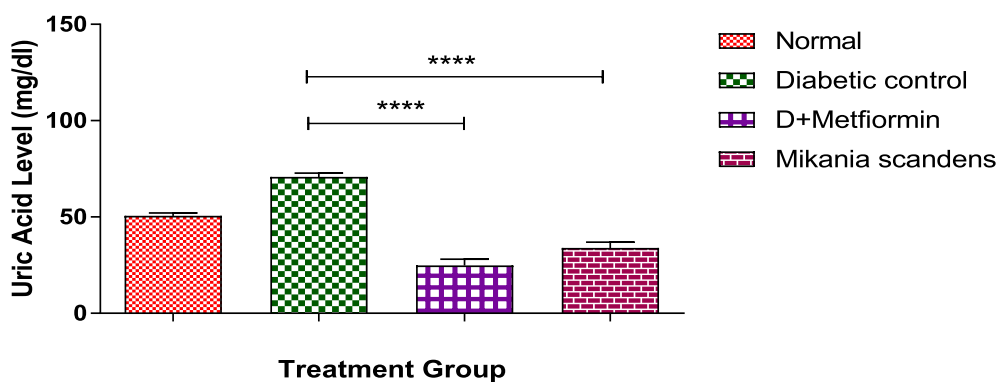

Fig. 4 Comparing the serum uric acid level among the diabetic control, metformin HCL and Mikania scandens animal groups. Significantly different $(p<0.05)$ from the diabetic control. Data were analyzed by one way ANOVA followed by scheffe's post-hoc test 


\section{Comparing Total Protein level between \\ Extract and Diabetic Control group}
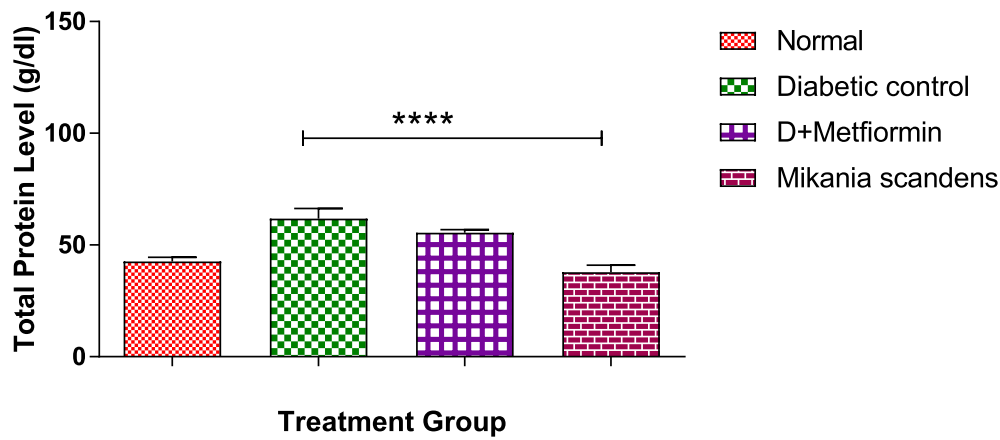

reatment Group

Fig. 5 Comparing total protein among diabetic control, metformin $\mathrm{HCL}$ and Mikania scandens animal group. Significantly different $(p<0.05)$ from the diabetic control. Data were analyzed by one way ANOVA followed by Scheffe's post-hoc test

micro vascular difficulties \& doubtlessly decrease the danger of macro vascular deforms [19].

Notable chemical compounds such as, alkaloids, flavonoids, phytosterol, phenolic compounds, tannins and glycosides were revealed in the ethanolic extract of $M$. scandens leaves [20]. Due to containing of phytosterol in Mikanina scandens leaves extract, it shows potent nephroprotective effect [21].

In body weight experiment, it was observed that normal control $47.6 \%$ weight gaining, Mikania scandens leave extract 9\% weight loss, standard treatment mice $6 \%$ weight loss, diabetic control $22.7 \%$ weight gaining at 22th day. Various plants extracts contain tannins, compounds that may exert an anti-nutritional impact by interfering with gut function [22] and minimize the glycaemic response to carbohydrate foods [23]. In standard group weight loss observed because the total adiposity or plasma leptin level, liver weight were significantly reduced after treatment with metformin [24]. In diabetic control group weight gaining occurred due to uric acid level that causes fluid accumulation [25].

In observation of blood glucose level Mikania scandens leaves extract decreased $77 \%$ blood glucose level, standard mice reduced $67 \%$ blood glucose level at 22th day. Both group lowered blood glucose at 15th and 22th

Table 6 Cytotoxic effect of EMSL on Brine shrimp lethality bioassay

\begin{tabular}{lll}
\hline Concentration & \% inhibition & LC $_{50}$ \\
\hline $100 \mu \mathrm{g} / \mathrm{ml}$ & 10 & \\
$200 \mu \mathrm{g} / \mathrm{ml}$ & 20 & \\
$400 \mu \mathrm{g} / \mathrm{ml}$ & 20 & $1083 \mu \mathrm{g} / \mathrm{ml}$ \\
$800 \mu \mathrm{g} / \mathrm{ml}$ & 40 & \\
\hline
\end{tabular}

day. In diabetic control mice, it was noticed that fluctuation of blood glucose level occurred. At 15th day $12.8 \%$ decreased and 22th day $60 \%$ increased blood glucose level. The fluctuation of blood glucose level of diabetic control mice is unknown. Further study is needed to explain this phenomenon.

The role of serum creatinine may also differ in patients with chronic kidney disease compared with healthy persons [26]. In present study, there was no significant result found of serum creatinine level among experimental, diabetic control and standard group on serum creatinine level. The cause of this result is unknown. Further study is needed to evaluate this result.

Uric acid is known to cause endothelial dysfunction, vascular smooth muscle cell proliferation, increased IL-6 synthesis, and impairment of nitric oxide production, all of which may contribute to the progression of chronic kidney disease [27]. In current study, there was increased in the level of uric acid level in alloxan induce diabetic nephropathy mice at 22th day when compared with no diabetic animal. Treatment with ethanolic extract of Mikania scandens leaves and metformin HCL groups exhibited significant $(p<0.05)$ reduction in uric acid when compared to diabetic control group animals.

High level of serum total protein level gradually diminishes renal function and formation of kidney stone [28]. In this study, there was increased in the level of total protein in alloxan induce diabetic nephropathy mice at 22th day when compared with no diabetic animals. Treatment with ethanolic extract of Mikania scandens leaves and Metformin HCL groups exhibited significant $(p<0.05)$ reduction total protein level on 22th day when compared to diabetic control group animal, which are mostly statically significant and show effective treatment era with highly nephroprotective activity. 


\section{Cyotoxicity}

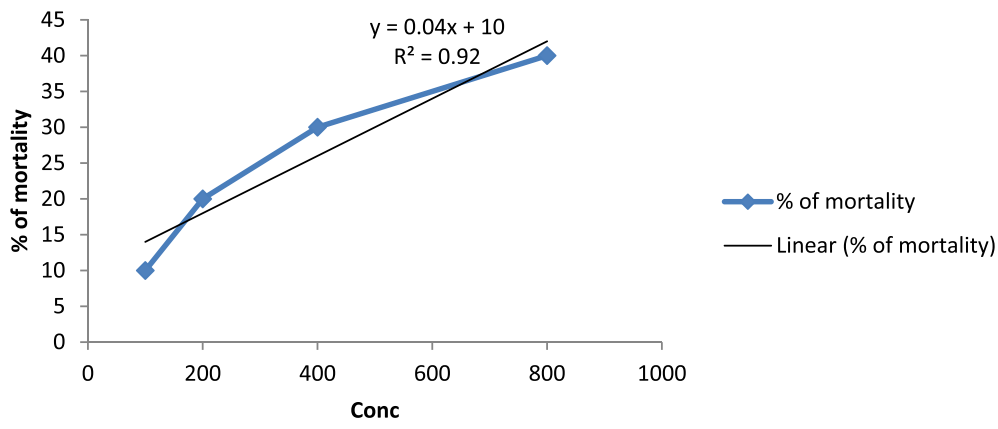

Fig. 6 Cytotoxic effect of Mikania scandens leaves extract

In cytotoxic test gradual increase of concentration of Mikania scandens leaves extract enhance the rate of mortality. $\mathrm{LC}_{50}$ value obtain from the test is $1083 \mu \mathrm{g} / \mathrm{ml}$ that indicates the $50 \%$ death occurs in this concentration. High dose of $\mathrm{LC}_{50}$ value indicates that it is out of danger to administer.

\section{Conclusion}

In this investigation, evaluation of body weight, blood glucose level, serum creatinine, uric acid and total protein levels in diabetic control group were significantly reversed by an ethanolic extract of Mikania scandens leaves in alloxan induce diabetic nephropathy mice. Therefore, this study suggested that ethanolic extract of Mikania scandens leaves showed their ability to attenuate the renal damage in diabetes.

\section{Abbreviations}

DM: Diabetes Mellitus; DN: Diabetic Nephropathy; LC $_{50}$ : Lethal Concentration

\section{Acknowledgements}

The authors are grateful to chairman, Department of pharmacy, Jashore University of Science and Technology, Jashore-7408, Bangladesh for providing laboratory facilities.

\section{Consent of publication}

Not applicable.

\section{Authors' contributions}

KA carried out all part of the experiment \& planning of this research, writing and editing of research paper. $\mathrm{MHHJ}$ helped in experimental analysis. MI helped in planning of the experiment and editing of this research paper. MBY helped in animal handling and take part in experiment. SMMR also helped in animal handling, take part in experiment and editing of this research paper. This research was supervised by RS. The authors read and approved the final manuscript.

\section{Funding}

This research was carried out by self-funding. There was no other funding source.

Availability of data and materials Not applicable.
Ethics approval and consent to participate

The study protocol was approved by institutional ethical committee (Ref No: ERC/FBS/JUST/2018-12).

\section{Competing interests}

The authors declare that they have no competing interests.

\section{Author details}

${ }^{1}$ Department of Pharmacy, Faculty of Biological Science, Jessore University of Science and Technology, Jessore 7408, Bangladesh. ${ }^{2}$ Department of Pharmacy, Faculty of Biological Science, Jessore University of Science and Technology, Jessore 7408, Bangladesh.

Received: 13 March 2019 Accepted: 12 March 2020

Published online: 06 April 2020

\section{References}

1. [No author listed]. USRDS: The United States renal data system. Am J Kidney Dis. 2003; 42(6 Suppl 5):1-230.

2. Vrhovac B, Jakšić B, Reiner Ž, Vucelić B. Interna medicina. Medicus. 2008; 17(1_Nutricionizam):157.

3. Kikkawa R, Koya D, Haneda M. Progression of diabetic nephropathy. Am J Kidney Dis. 2003;41(3):S19-21.

4. Fernandez-Fernandez B, Ortiz A, Gomez-Guerrero C, Egido J. Therapeutic approaches to diabetic nephropathy beyond the RAS. Nat Rev Nephrol. 2014:10(6):325.

5. Guyton Arthur C, Hall JE. Textbook of Medical Physiology. Philadelphia: Elsevier Saunders; 2016. p. 310. ISBN 0-7216-0240-1.

6. "Diabetic nephropathy" Retrieved. 2015-6-27..

7. Moon M, Rattray MR, Putz FE, Bowes G. Acclimatization to flooding of the herbaceous vine, Mikania scandens. Funct Ecol. 1993;1:610-5.

8. Gasparetto JC, Campos FR, Budel JM, Pontarolo R. Mikania glomerata Spreng. e M. laevigata Sch. Bip. ex Baker, Asteraceae: Agronomic, genetic, anatomical, chemical, pharmacological, toxicological studies and its use in herbal therapy programs in Brazil. Revista Brasileira de Farmacognosia. 2010; 20(4):627-40.

9. Herz W, Subramaniam PS, Santhanam PS, Aota K, Hall AL. Structure elucidation of sesquiterpene dilactones from Mikania scandens. J Org Chem. 1970;35(5):1453-64.

10. Tangjang S, Namsa ND, Aran C, Litin A. An ethnobotanical survey of medicinal plants in the eastern Himalayan zone of Arunachal Pradesh, India. J Ethnopharmacol. 2011;134(1):18-25.

11. Novy JW. Medicinal plants of the eastern region of Madagascar. J Ethnopharmacol. 1997;55(2):119-26.

12. Chandra S, Dey P, Bhattacharya S. Preliminary in vitro assessment of antiinflammatory property of Mikania scandens flower extract. J Adv Pharm Edu Res. 2012;2(1):25-31.

13. Hasan SR, Mariam J, Majumder MM, Raushanara A, Hossain MM, Mazumder ME, Alam MA, Rumana J, Rana MS, Arif M, Rahman S. Analgesic and antioxidant activity of the hydromethanolic extract of Mikania scandens (L.) Willd. Leaves. Am J Pharmacol Toxicol. 2009;4(1):1-7. 
14. Harwig J, Scott PM. Brine shrimp (Artemia salina L.) larvae as a screening system for fungal toxins. Appl. Environ. Microbiol. 1971;21(6):1011-6.

15. Nasrin F, Hakim ML, Hassan MR, Afroz N, Ikbal MH, Azam S. Hypoglycemic study of ethanolic extract of Mikania cordata leaf. World J Pharmaceutical Res. 2015;4(7):01-9.

16. Meyer BN, Ferrigni NR, Putnam JE, Jacobsen LB, Nichols DJ, McLaughlin JL. Brine shrimp: a convenient general bioassay for active plant constituents. Planta Med. 1982;45(05):31-4.

17. Katewa SS, Chaudhary BL, Jain A. Folk herbal medicines from tribal area of Rajasthan, India. J Ethnopharmacol. 2004;92(1):41-6.

18. Eff C, Faber $\mathrm{O}$, Deckert T. Persistent insulin secretion, assessed by plasma Cpeptide estimation in long-term juvenile diabetics with a low insulin requirement. Diabetologia. 1978;15(3):169-72.

19. Latha M, Pari L, Sitasawad S, Bhonde R. Insulin-secretagogue activity and cytoprotective role of the traditional antidiabetic plant Scoparia dulcis (sweet Broomweed). Life Sci. 2004;75(16):2003-14.

20. Joarder MH, Islam MU, Ahamed K, Yameen MB, Sharmin R. Mikania Scandens leaves possess potent \& prolong Antidiabetic effect in Alloxan induced diabetes mice. J Biomed Pharm Sci. 2019;2(117):2.

21. Sharmila R, Sindhu G, Arockianathan PM. Nephroprotective effect of $\beta$ sitosterol on $\mathrm{N}$-diethylnitrosamine initiated and ferric nitrilotriacetate promoted acute nephrotoxicity in Wistar rats. J Basic Clin Physiol Pharmacol. 2016;27(5):473-82.

22. Carbonaro M, Grant G, Pusztai A. Evaluation of polyphenol bioavailability in rat small intestine. Eur J Nutr. 2001;40(2):84-90.

23. Gin H, Rigalleau V, Caubet $\mathrm{O}$, Masquelier J, Aubertin J. Effects of red wine, tannic acid, or ethanol on glucose tolerance in non-insulin-dependent diabetic patients and on starch digestibility in vitro. Metabolism. 1999:48(9):1179-83.

24. Pelantová H, Bugáňová M, Holubová M, Šedivá B, Zemenová J, Sýkora D, Kaválková P, Haluzík M, Železná B, Maletínská L, Kuneš J. Urinary metabolomic profiling in mice with diet-induced obesity and type 2 diabetes mellitus after treatment with metformin, vildagliptin and their combination. Mol Cell Endocrinol. 2016:431:88-100.

25. The Times of India. (2019). How to reduce uric acid levels in body - Times of India. [online] Available at: https://timesofindia.indiatimes.com/life-style/ health-fitness/health-news/How-to-reduce-uric-acid-levels-in-body/ articleshow/18725896.cms [Accessed 26 Feb. 2019].

26. Rule AD, Larson TS, Bergstralh EJ, Slezak JM, Jacobsen SJ, Cosio FG. Using serum creatinine to estimate glomerular filtration rate: accuracy in good health and in chronic kidney disease. Ann Intern Med. 2004;141(12):929-37.

27. Siu YP, Leung KT, Tong MK, Kwan TH. Use of allopurinol in slowing the progression of renal disease through its ability to lower serum uric acid level. Am J Kidney Dis. 2006;47(1):51-9.

28. Hotta M, Ohwada R, Akamizu T, Shibasaki T, Kangawa K. Therapeutic potential of ghrelin in restricting-type anorexia nervosa. In: Methods in enzymology, vol. 514: Academic Press; 2012. p. 381-98.

\section{Publisher's Note}

Springer Nature remains neutral with regard to jurisdictional claims in published maps and institutional affiliations.

\section{Submit your manuscript to a SpringerOpen ${ }^{\odot}$ journal and benefit from:}

- Convenient online submission

- Rigorous peer review

- Open access: articles freely available online

- High visibility within the field

- Retaining the copyright to your article

Submit your next manuscript at $\boldsymbol{\nabla}$ springeropen.com 